\title{
Anthropogenic stressors are driving a steep decline of hemipteran diversity in dune ponds in north-eastern Algeria
}

Nouara Benslimane1,2 · Khémissa Chakri1,2 · Dalal Haiahem1 · Anis Guelmami3 · Farrah Samraoui1,4 · Boudjéma Samraoui1,2

Boudjéma Samraoui : bsamraoui@gmail.com

1 Laboratoire de Conservation des Zones Humides, Université 8 Mai 1945 Guelma, Guelma, Algeria

2 Department of Biology, University of Annaba, Annaba, Algeria

3 Tour du Valat, Research Institute for the Conservation of Mediterranean Wetlands, Tour du Valat, le Sambuc, 13200 Arles, France

4 Department of Ecology, Université 8 Mai 1945 Guelma, Guelma, Algeria

How to cite : Benslimane N., Chakri K., Haiahem D., Guelmami A., Samraoui F., Samraoui B. 2019. Anthropogenic stressors are driving a steep decline of hemipteran diversity in dune ponds in north-eastern Algeria. Journal of Insect Conservation 10.1007/s10841-019-00133-1.

\section{Abstract}

In arid North Africa, dune ponds qualify as hotspots of aquatic biodiversity, offering numerous sustainable ecosystem ser- vices. Despite mounting anthropogenic pressures that threaten their integrity, the overall consequences of these changes have yet to be documented and no strategy to mitigate potential impacts is being implemented. We monitored four dune ponds in northeast Algeria during five hydrological cycles spanning the period 1996-2013. The analysis revealed a steep decline in species richness (47\%) and abundance (94\%) over the study period. Remote sensing-based data indicated that marked human-induced changes in and around these dune ponds have over time led to a substantial expansion of built areas and cultivated plots and a reduction in both natural wet- and dry-land habitats. Fish predation by the introduced fish, Gambusia holbrooki, may have had both direct and indirect impacts on notonectids. We argue that aquatic hemipterans have undergone an alarming reduction driven by a combination of invasive species, human encroachment, agricultural runoffs, and possibly, climate change.

Keywords Aquatic hemiptera · Climate change · Ecosystem services · Mosquitofish · North Africa · Remote sensing · Temporary ponds

\section{Introduction}

Freshwater biodiversity is imperiled worldwide because water is increasingly in high demand by a growing human population and under threat from a range of stressors like pollution, invasive species and climate change (Vörösmarty et al. 2010; Bunn 2016). The high rate of species decline infreshwater ecosystems may qualify them as the most endangered ecosystems (Sala et al. 2000; Dudgeon et al. 2006). Similarly threatened, small water bodies often have a greater diversity of aquatic organisms than lakes and rivers (Wil- liams et al. 2003; Davies et al. 2008) and their importance for rare, endangered or endemic species cannot be overstated (Collinson et al. 1995; Della Bella et al. 2005).

As small water bodies, ponds play a major role in bio- geochemical cycles (Downing 2010) and provide essen- tial ecosystem services such as primary production, water purification, and nutrient cycling (Céréghino et al. 2014; Mitsch et al. 2015). Furthermore, temporary ponds have also established themselves as a convenient arena for ecological research (Wilbur 1997) and their typical characteristics, such as shallow waters and small size, suggest a distinct ecologi- cal function (Oertli et al. 2002). In addition, over the last two decades, temporary ponds have become the center of a growing interest in the conservation of aquatic organisms and their habitats (Oertli et al. 2005).

As could be expected, water is scarce in North Africa's desert regions like the Maghreb, amounting to a strategic resource. Whereas vast salt lakes are the dominant wetlands in the arid and semi-arid North African Hauts Plateaux and Sahara (Demnati et al. 2017), temporary pools and dune ponds are the most frequent freshwater wetlands along the Mediterranean, especially in northeast Algeria (Samraoui and Bélair 1997, 1998). Dune ponds are not only unique freshwa- ter ecosystems in the North African landscape; they are also biodiversity hotspots and sanctuaries for relict dragonfly and zooplankton species (Samraoui et al. 1993, 1998). However, following a worldwide trend (Brinson and Malvárez 2002), North African freshwater ecosystems have been facing unre- lenting anthropogenic pressures in the past decades (Hollis 1992; Bélair and Samraoui 1994).

Despite the large spectrum of ecological services provided (Losey and Vaughan 2006), insects are undergoing a rapid decline worldwide with cascading effects on trophic webs (Thomas et al. 2004; Conrad et al. 2006; Hallmann et al. 
2017). Amidst these long-term changes and Anthropocene defaunation, insect conservation has been hindered by a number of obstacles including knowledge gaps (Cardoso et al. 2011; Dirzo et al. 2014). For instance, aquatic hemipterans are considered potential bioindicators of water quality (Jansson 1977; Savage 1990) which may be used in regional or global conservation planning of freshwater biodiversity (Polhemus and Polhemus 2008) but their status and knowledge of their ecology are still fragmentary (Papáček 2001).

The loss and major alterations of local wetlands have been associated with a concomitant disturbing decline in their biota (Samraoui et al. 2012) but efforts to mitigate these downward trends are hampered by an inadequate knowledge of the status of most species. In the last three decades, only two system- atic surveys of the hemipterans of Algeria have been carried out, providing much-needed information on the distribution, phenology and status of this much-neglected group of aquatic insects (Tebibel 1992; Annani et al. 2012).

However, this limited information may already be outdated as the spread of the eastern mosquitofish, Gambusia holbrooki, as a biological control agent throughout Algeria has had an adverse impact on the indigenous fauna (Haiahem et al. 2017). Mosquitofish have been introduced worldwide (Botsford et al. 1987) but the benefits of such endeavour (mosquito control) remain controversial while the drawbacks are well documented (Hurlbert et al. 1972; Pyke 2008). The present work aims to assess the potential impact of pervasive stressors (invasive fish, human encroachment, pollution, and climate change) on four dune ponds in northeast Algeria by monitoring the status of their aquatic hemipteran communities over a 17-year period.

\section{Materials and methods}

\section{Study area}

Numidia, in northeast Algeria, has a diversity of aquatic habitats, including freshwater lakes, ponds, lagoons, and brackish marshes (Samraoui and Bélair 1997, 1998). The region encompasses a Biosphere Reserve, the El Kala National Park, and numerous Ramsar sites and Impor-tant Bird Areas (Samraoui and Samraoui 2008) (Fig. 1). Numidia's climate is typically Mediterranean, being characterized by a mild and unpredictable rainy season between October and April (600-800 mm), and a hot, dry season exceeding 5 months from May to September. Four dune ponds, all located within Numidia, northeastern Algeria, were selected. The word 'Garaet' (lake/pond) is abbreviated to 'G':

1. G. Estah $\left(36^{\circ} 50.556^{\prime} \mathrm{N}, 7^{\circ} 58.939^{\prime} \mathrm{E}\right)$ : A temporary pond of 8 ha with Nymphaea alba, Phragmites australis, Scirpus lacustris, Salix atrocinerea, and Iris pseudo-acorus. Because of the proximity of the Mekhada marsh, the non-native mosquitofish (Gambusia holbrooki) was pre- sent at Estah at the beginning of the sampling period. 2. G. Dakhla $\left(36^{\circ} 50.674^{\prime} \mathrm{N}, 7^{\circ} 59.077^{\prime} \mathrm{E}\right)$ : A temporary pond of 8 ha, adjacent to G. Estah with Phragmites australis, Cladium mariscus, Scirpus lacustris, and Nym-phaea alba.

2. Lac Bleu $\left(36^{\circ} 54^{\prime} \mathrm{N}, 8^{\circ} 20^{\prime} \mathrm{E}\right)$ : A protected (Ramsar Site) permanent pond of 4 ha located within the El Kala National Park. The vegetation is dominated by Phrag-mites australis, Nymphaea alba, and Ceratophyllum demersum. Lac Bleu was one of the last strongholds of the Killifish Aphanius fasciatus in Numidia.

3. Saulaie: A temporary dune slack, adjacent to Lac Bleu, dominated by Salix cinerea, Iris pseudoacorus, Carex elata, and Scirpus lacustris.

Estah and Saulaie are temporary ponds which dry up during the summer months and early autumn whereas Dakhla dries up only during severe droughts. Estah har-boured mosquitofish at the start of the study while the other three dune ponds were initially devoid of mos-quitofish until they were invaded in 2010 (Dakhla) and 2012 (Lac Bleu and Saulaie).

\section{Land use and land cover change monitoring}

The spatiotemporal dynamics of land use and land cover (LULC) in and around the studied sites (using $1 \mathrm{~km}$ buffer zone) were assessed by earth observation (EO) tools. Thus, based on Landsat time series, covering 4 years (1992, 1999, 2007 and 2015), it was possible to produce LULC maps using an object-based approach (images segmenta- tion and classification) and implementing a hybrid nomen- clature system that integrates all wetland habitats (accord- ing to Ramsar definitions) into the CORINE Land Cover typology. All the resulting products were then integrated into a geographic information system (GIS) and different indicators, related to habitat extents and their trends, were computed and used for further statistical analyses. All workflows for satellite images processing were car- ried out using the 
GEOclassifier 1.4 .8 software (Jena- Optronik GmbH 2018) and the spatial analyses ArcGIS 10.3 TM (2014).

Fig. 1 The location of the study sites across eastern Numidia (1: G. Estah, 2: G. Dakhla, 3: Lac Bleu, and 4: Saulaie)

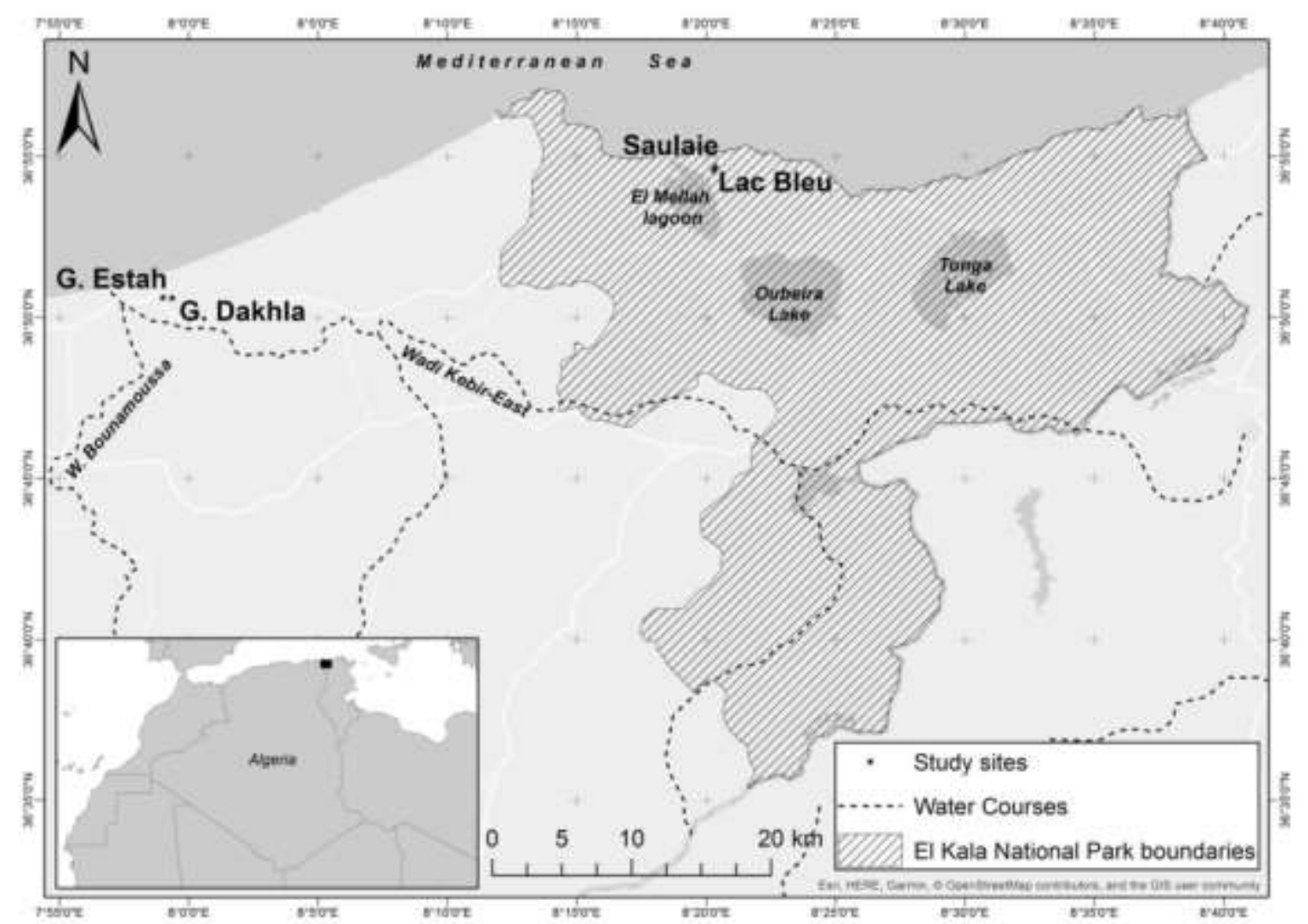

\section{Aquatic sampling}

Aquatic hemipterans and fish were collected monthly throughout the year for Lac Bleu, a permanent pond, and covering the ponds' hydrological regimes for the other three temporary sites: the first two cycles spanned the hydroperi- ods of 1996-1998 (June 1996-May 1998) whereas the last three cycles covered the following seasons: 2010-2013 (June 2010-May 2013). Samples were collected using a dipnet (300 $\mu \mathrm{m}$ mesh size, $35 \mathrm{~cm}$ diameter) and were fixed in $5 \%$ formaldehyde. Each site was sampled along a $50 \mathrm{~m}$ transect using ten dipnet sweeps ( $3 \mathrm{~m}$ long) across all microhabitats along the bank edge. Deeper submerged parts of the study sites were not sampled.

Each sample was preceded by measures of the average water depth, and water temperature, recorded between 9 a.m. and 11 a.m. Water conductivity was only recorded for the last four hydrological cycles using a Hanna instruments HI 8733. In the laboratory, samples were sorted, and Hemip-tera were counted and identified to species with taxonomic keys (Tachet et al. 2010) and confirmed using the University of Annaba's Laboratoire de Recherche des Zones Humides reference collection. Because some aquatic sampling could not be performed due to summer drought, only water tem- perature values from December to February were taken into account, and combined into two distinct periods (1996-1998 and 2010-2013).

\section{Statistical analyses}

Hemipteran community structure was investigated using species richness and Simpson's diversity index. Linear regressions were used to explore whether Hemiptera total abundance or species richness changed over time and were thus related to cycle order. One-way ANOVA tests were performed followed by Post hoc (Tukey) tests to distinguish the mean differences which are significantly different. Non- parametric tests were used when assumptions of normality and homogeneity of variance could not be met. All statistical analyses, including a Principal Component Analysis (PCA) were carried out using R (R Development Core Team 2017). 
Between 1992 and 2015, there was a notable increase in human activities across the whole eastern Numidian dune system which stretches from G. Estah/G. Dakhla to Lac Bleu/Saulaie. EO-based LULC maps indicated that agricul- tural lands increased while natural dryland (forests, shrubs and herbaceous vegetation) and wetlands declined (Table 1). Interestingly, changes in land use were not uniform across the dune system. The extension of built-up areas and roads was concentrated around Lac Bleu and Saulaie, which are part of the El Kala National Park, and the town of El Kala and its suburbs (Fig. 2). In contrast, there was a greater expansion of agriculture area and a concomitant larger loss of natural vegetation cover in the vicinity of $\mathrm{G}$. Estah and

G. Dakhla (Fig. 3). In addition, surface areas of natural wet- lands incurred more habitat loss near these unprotected sites.

There was a marked seasonal change in water depth but fluctuations were similar across years, ranging from $16 \mathrm{~cm}$ (Saulaie, August 2012) to $110 \mathrm{~cm}$ (Dakhla, Febru- ary 2013), The overall mean water temperatures of the first two sampling periods (1996-1998 and 2010-2013) were

$11.4 \pm 1.7^{\circ} \mathrm{C}$ and $12.9 \pm 1.9^{\circ} \mathrm{C}$, respectively. The increase in water temperature during the second period $\left(1.5^{\circ} \mathrm{C}\right)$ was significant (One-way ANOVA: $\mathrm{F} 1,55=8.7, \mathrm{p}<0.005)$. Mean water conductivity in the second cycle $(0.49 \mathrm{mS} / \mathrm{cm}$ ) was significantly higher than those recorded in subsequent cycles $(0.30-0.34 \mathrm{mS} / \mathrm{cm})$ (One-way ANOVA: F3,92 = 9.6, $p=1.4$ e-05).

Of significance was the first ever record, during the third hydrological cycle, of Gambusia holbrooki at Dakhla. Mosquitofish were able to reach Dakhla between 2000 and 2006, when locals dug a trench linking this latter site to G. Estah. In addition, during the last hydrological cycle, the non-native mosquitofish managed to invade both Lac Bleu and Saulaie but how this was achieved remains unknown.

The five hydrological cycles yielded 18 hemipteran species that were identified from the 7120 recorded aquatic hemipterans (Table 2). There was a down-ward trend of total abundance (linear regression: abun- dance $=-122.8 \times$ cycle $+724.3, \mathrm{R} 2=0.27, \mathrm{p}=0.02$ ) (Fig. $4 \mathrm{a}$ ) and species richness (linear regression: species richness $=-1.8 \times$ cycle $+13.9, \mathrm{R} 2=0.60, \mathrm{p}<0.0001$ ) (Fig. 4b). Compared to the first hydrological cycle which provided 2181 hemipterans, the fifth and last cycle only hosted 123 hemipterans, displaying a drop in abundance of $94 \%$. Over the same period, species richness decreased by 47\%. Only eight species, Nepa cinerea, Corixa affinis, Corixa panzeri, Hesperocorixa linnaie, Hesperocorixa moesta, Sigara lateralis, Anisops sardea, and Plea minitussima, were recorded during the last hydrological cycle. In contrast, Shannon's diversity index showed a relative stability over the first four sampling periods before undergoing a marginal decrease in the last hydroperiod (Kruskal-Wallis: $\chi 2=3.84, d f=4, p=0.43$; generalized additive model: $\mathrm{F} 2,17=1.99, \mathrm{p}=0.17$, explained deviance $=18.9 \%$ ) (Fig. $4 \mathrm{c}$ ).

A Principal Component Analysis was performed (20 samplings $\times 18$ species) and four components, representing $63.6 \%$ of the total inertia, were retained (Fig. $5 a$, b). The first component ( $23.9 \%$ of the total variance) was associated with high abundance of Notonectidae and the absence of fish. Dakhla and Saulaie in the first 20 years of sampling were characteristic sites of this first component. This component also included the second cycle of Estah which had its mos- quitofish population decimated by a summer drought. The second component (16\%) was associated with a high abun- dance of large-sized corixids and the absence of Notonecta. This assemblage was best represented by Dakhla after mos- quitofish invaded this site during the third hydrological cycle. The third component (12.3\%) opposed a high abun- dance of mosquitofish to species sensitive to fish predation like Hesperocorixa moesta and Notonecta glauca while the fourth component (10.9\%) was associated with the presence of the rare relict belostomid Hydrocyrius columbiae (Sup- plemental Fig. A).

The impact of mosquitofish on the aquatic hemipter- ans was uneven, varying according to taxa (Fig. 6). The abundance of Notonectidae declined significantly in the presence of Gambusia holbrooki (Kruskal-Wallis: $\chi 2=$ $5.2, \mathrm{df}=1, \mathrm{p}=0.02$ ) (Fig. 6a) whereas the Corixidae did not seem to be affected significantly (Kruskal-Wallis: $\chi 2=0.01$, $\mathrm{df}=1, \mathrm{p}=0.93$ ) (Fig. 6b). However, within the Corixidae, some taxa, like Hesperocorixa moesta, were reduced significantly when associated with mosquitofish (Kruskal-Wallis: $\chi 2=5.5, d f=1, p=0.02$ ) (Fig. $6 c$ ). The mean abundance of other taxa, like Gerris thoracicus, declined but an association with mosquitofish was only marginally significant (Kruskal-Wallis: $\chi 2=2.5, \mathrm{df}=1, \mathrm{p}=0.11$ ). 
Table 1 Percent changes in landscape features between 1992 and 2015 around each study sites

\begin{tabular}{lcccc}
\hline Landscape features & G. Dakhla & G. Estah & Lac Bleu & Saulaie \\
\hline Roads, paths and built-up areas & -1.7 & -3.9 & 57.8 & 68.9 \\
Agricultural lands & 314.7 & 307.2 & 7.1 & 30.9 \\
Natural drylands & -37.6 & -39.2 & -3.5 & -4.6 \\
Natural wetlands (Ramsar definitions) & -9.1 & -2.1 & -0.8 & -0.6 \\
\hline
\end{tabular}

Fig. 2 Changes in landscape cover in a 1 km buffer zone around Lac Bleu and Saulaie in 1992, 1999, 2007, and 2015
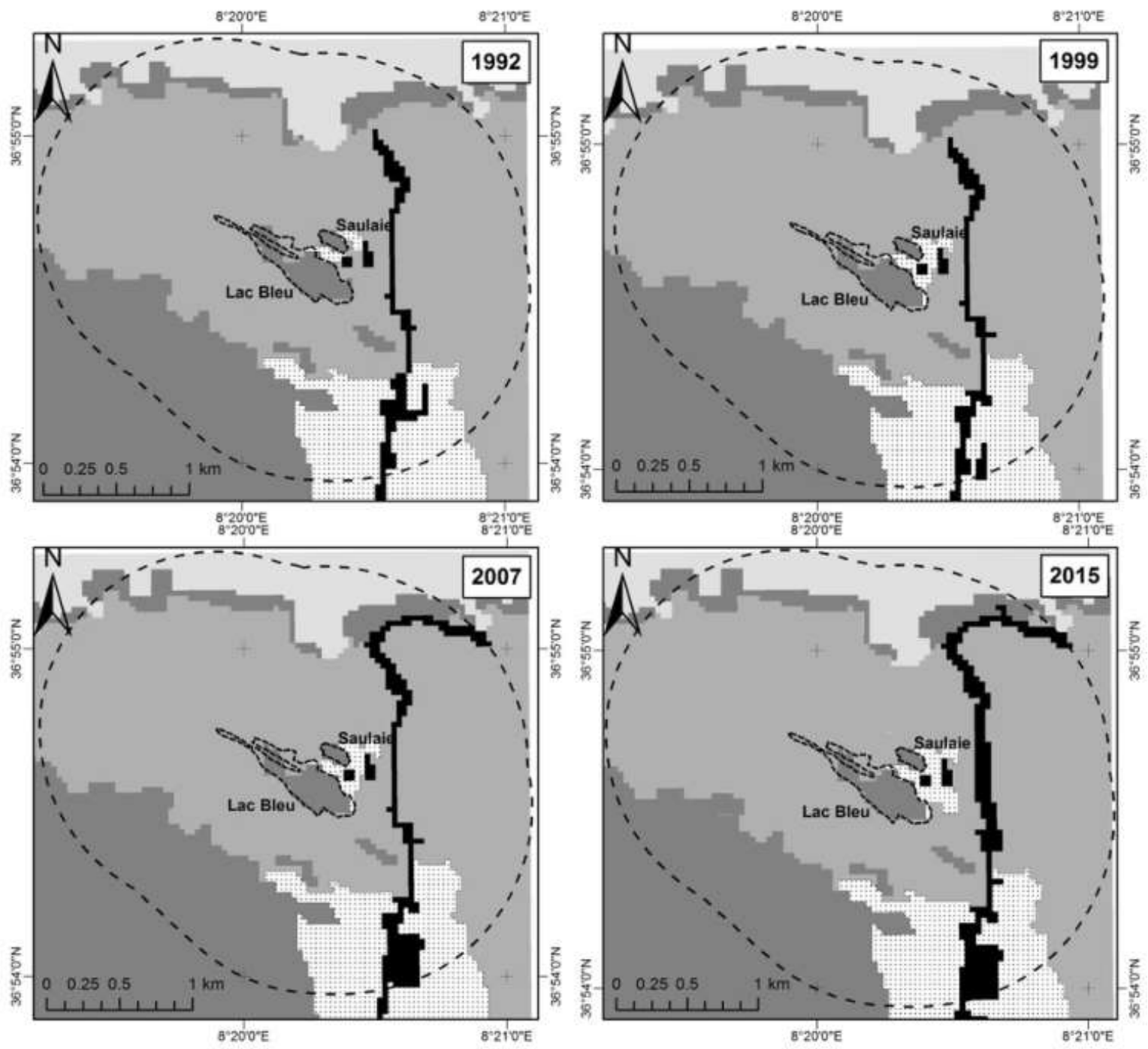

$\begin{array}{r}- \\ \hdashline\end{array}$

Roads, paths and built-up areas

Agricultural lands

Natural drylands

Natural wetlands

Human-made wetlands

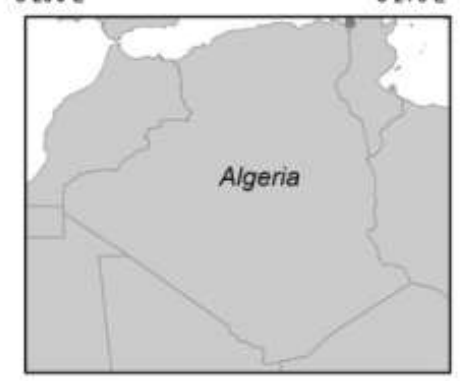

Sea 

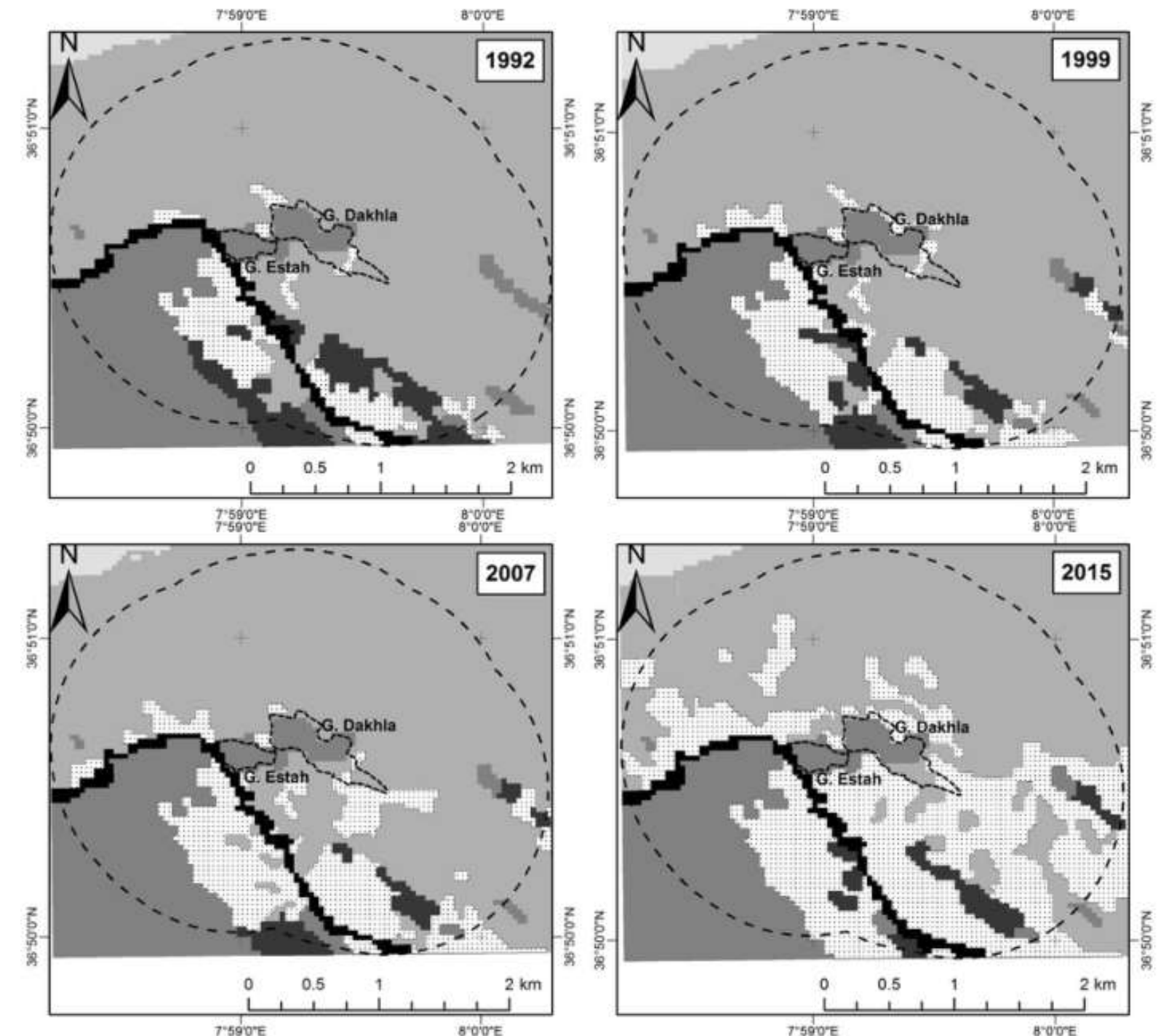

-

$11 \mathrm{~km}$ buffer zone

Roads, paths and built-up areas

Agricultural lands

Natural drylands

Natural wetlands

Human-made wetlands

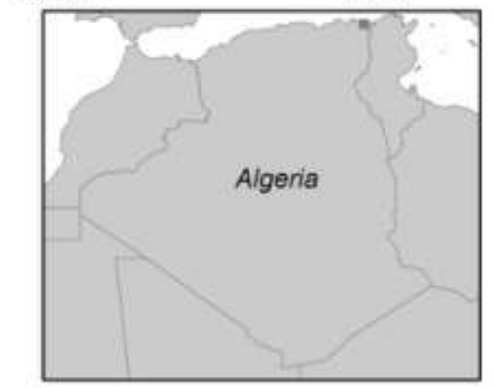

Sea

\section{Discussion}

Dune ponds are essential elements of the Numidian land- scape habitat mosaics which provide a rich array of landscape functions (Bélair and Samraoui 1994; Samraoui and Bélair 1997). However, in line with what is happening worldwide, human activities have been eroding landscape functions by altering connectivity between ponds and other landscape elements (Carpenter et al. 2011). The magnitude of the recorded changes in the Numidian dune system weakens the connectivity of the study ponds to other landscape elements, and thus influence ecosystem functions and ser- vices (Mitchell et al. 2013).

One basic function of dune ponds, biodiversity support, seemed to have been markedly undermined during the study period. Altogether, 18 species of aquatic hemipterans were 
Table 2 Check-list of aquatic hemipterans recorded during the study period

\begin{tabular}{|c|c|c|c|c|c|}
\hline & Species & Code & $1996-1998$ & $2010-2012$ & $2012-2013$ \\
\hline 1 & Hydrocyrius columbiae Spinola & Hco & Lac Bleu, Saulaie, Estah, Dakhla & Lac Bleu, Dakhla & \\
\hline 2 & Nepa cinerea Linne & Nei & Dakhla & Lac Bleu, Saulàe & Lac Bleu \\
\hline 3 & Ranatra linearis Linné & Rli & Dakhla & Saulaic & \\
\hline 4 & Corixa panzeri (Fieber) & Cpa & Lac Bleu, Saulaie, Estah, Dakhla & $\begin{array}{l}\text { Lac Bleu, Saulaie, Estah. } \\
\text { Dukhla }\end{array}$ & Lac Bleu, Estah, Dakhla \\
\hline 5 & Corixa affinis Leach & Caf & Lac Bleu, Saulaie, Estah, Dakhla & $\begin{array}{l}\text { Lac Bleu, Saulaie, Estah, } \\
\text { Dakhla }\end{array}$ & Lac Bleu, Estah, Dakhla \\
\hline 6 & Corixa punctata (Illiger) & Cpu & & Dakhla & \\
\hline 7 & Hesperocoriza finnaei (Fieber) & $\mathrm{HIi}$ & Lac Bleu, Saulaie, Estah, Dakhla & $\begin{array}{l}\text { Lac Bleu, Saulaic, Estah, } \\
\text { Dakhla }\end{array}$ & $\begin{array}{l}\text { Lac Bleu, Saulaie, Estah, } \\
\text { Dakhla }\end{array}$ \\
\hline 8 & Hesperocorixa moesta (Fieber) & Hmo & $\begin{array}{l}\text { Lac Bleứ, Saulaie, Estah, } \\
\text { Dakhla }\end{array}$ & $\begin{array}{l}\text { Lac Bleu, Saulaie, Estah. } \\
\text { Dakhla }\end{array}$ & Latc Bleu \\
\hline 9 & Hesperocorixa furtiva (Horvath) & Hfu & Saulaie, Estah & Saulaie, Estah, Dakhla & \\
\hline 10 & Sigara scripta (Rambur) & & Lac Bleu" & & \\
\hline 11 & Sigara nignolineata (Fieber) & & Saulaie ${ }^{2}$ & & \\
\hline 12 & Nigara lateralis (Leach) & Sla & Saulaie, Estah, Dakhla & $\begin{array}{l}\text { Lac Bleu, Saulaie, Estah, } \\
\text { Dakhla }\end{array}$ & Estah \\
\hline 13 & Parasigara favieri (Poisson) & & Saulaie $^{4}$, Dakhla ${ }^{2}$ & & \\
\hline 14 & Microntecta scholtzi (Fieber) & & Lac Bleu" & & \\
\hline 15 & Micronecta sp & & Lac Bleu" & & \\
\hline 16 & Notonecta glauca Poisson & $\mathrm{Ngl}$ & Lac Bleu, Saulaie, Estah, Dakhla & Lac Bleu, Saulaie, Estah & \\
\hline 17 & Notonecta meridionalis Poisson & Nob & Lac Bleu, Saulaic, Estah, Dakhla & Lac Bleu, Saulaic, Estah & \\
\hline 18 & Notonecta viridis Delcourt & Nvi & Dakhla & & \\
\hline 19 & Anisops sardea Herrich-Schaffer & Asa & Lac Bleu, Saulaie, Estah, Dakhla & $\begin{array}{l}\text { Lac Bleu, Saulaic, Estah. } \\
\text { Dakhla }\end{array}$ & Dakhla \\
\hline 20 & Plea minutissima Leach & Pmi & Lac Bleu, Saulaic, Estah, Dakhla & $\begin{array}{l}\text { Lac Bleu, Saulaie, Estah, } \\
\text { Dakhla }\end{array}$ & Lac Bleu \\
\hline 21 & Naucoris maculatus Fabricius & Nma & Lac Bleu, Saulaie, Estah, Dakhla & Lac Bleu, Saulaie, Estah & \\
\hline 22 & Hydrometra stagnarum (Linné) & & Saulaie ${ }^{i}$ & & \\
\hline 23 & Gerris thoracicus Schummel & Gth & $\begin{array}{l}\text { Lac Bleu", Saulaie, Estah, } \\
\text { Dakhla }\end{array}$ & Saulaie, Estah, Dakhla & \\
\hline 24 & Mesolvelia vittigena Horvath & Mvi & Lac Bleu, Saulaie, Estah, Dakhla & & \\
\hline
\end{tabular}

Known records from Annani et al. (2012) are marked with superscript " $a$ "

identified with the four study ponds. This number can be put into context by comparing it with the result from another survey which sampled 83 distinct sites across north-eastern Algeria and recorded 35 species (Annani et al. 2012). The high percentage of species recovered from our study (54\%) is even more remarkable as Annani et al. (2012)'s sampling included semi-arid areas and both lotic and lentic habitats. This result is congruent with previous work highlighting the remarkable biodiversity of small water bodies, often domi- nated by hemipterans and coleopterans (Nicolet et al. 2004; Zacharias et al. 2007; Bilton et al. 2009).

However, both the overall abundance and species richness of aquatic hemipterans exhibited a significant decrease in numbers. While the abundance and species richness exhibited a gradual but steep decline over time, Shannon's diversity index was relatively stable until the last sampling year when it displayed a marginal drop. When abundance varies significantly between samples, the interpretation of results may depend on the choice of the diversity index (Magurran 1988).

Two clear community structures, dominated by notonectids and corixids, respectively, emerged from the multivariate analysis. Although the detailed trophic posi- tion of most corixids and notonectids is poorly known (Klecka 2014), their differential distribution across the study ponds and hydrological cycles suggest distinct responses to anthropogenic pressures that may shed some light on the food web structures of dune ponds. 
Altogether, three anthropogenic stressors have been identified (invasive fish, human encroachment including agricultural runoff, and global warming) but disentangling the separate impact of each of these recorded stressors on the study ponds would require an experimental approach.

Fig. 4 Trend in abundance (a), species richness (b), and Shannon's diversity index (c) of aquatic hemipterans in the study ponds during five hydrological cycles

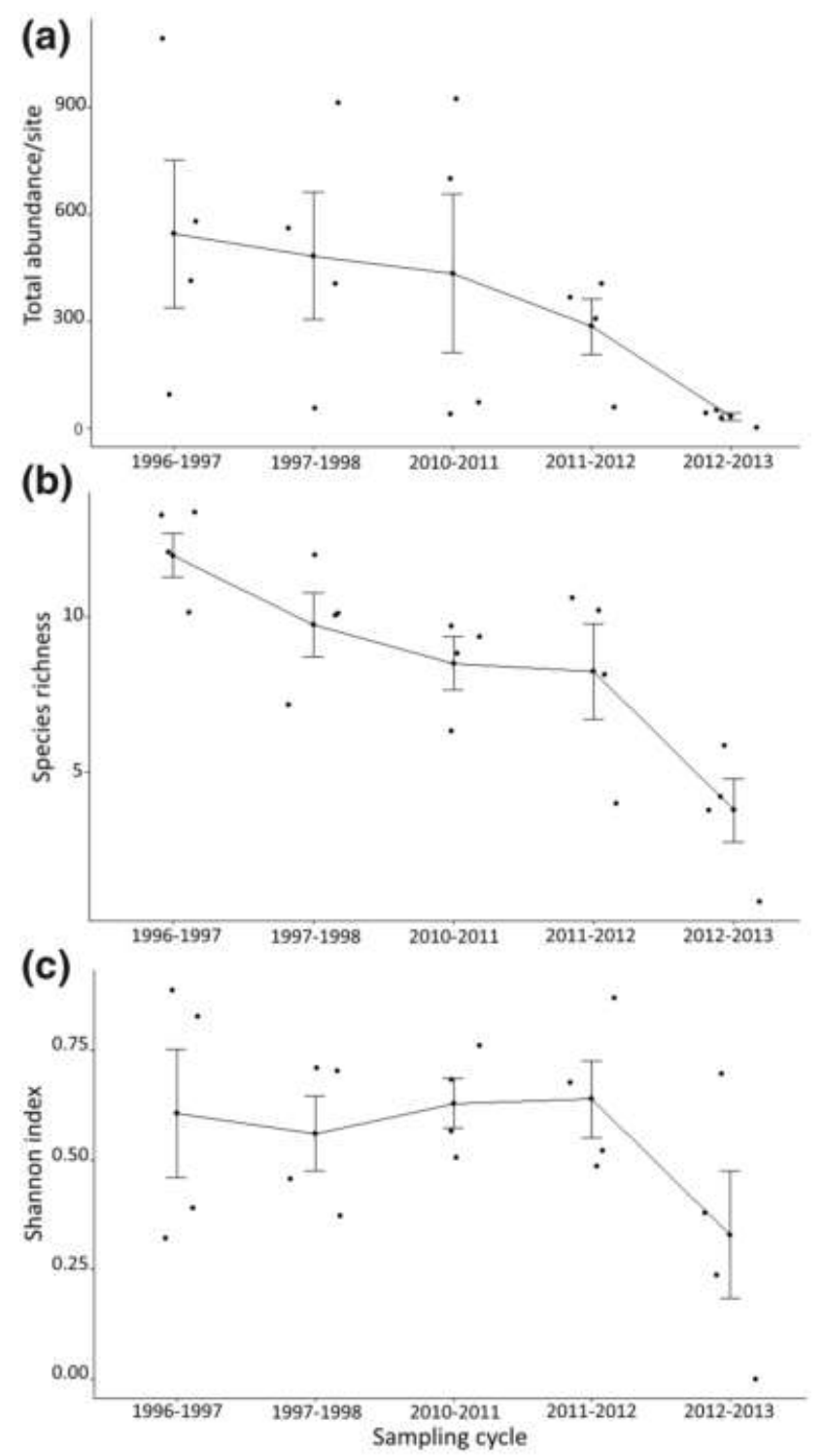

However, we will review each factor in turn and attempt to discuss potential impacts and implications.

\section{Invasive fish}

Predation is a major driver of food web structure (Zaret 1980). Selective predation by fish or notonectids may reduce the abundance of large zooplankton and alter species compo- sition and diversity of freshwater communities (Batzer and Wissinger 1996; Shurin 2001). In Algeria, it has been shown that predatory mosquitofish can deplete the zooplankton assemblages of both permanent lakes and temporary ponds (Samraoui 2002; Haiahem et al. 2017). Thus, a shortage of zooplankton caused by fish predation may have negative consequences on predatory aquatic insects like notonectids which also rely heavily on this type of prey (Murdoch et al. 1984).

Our study indicated a differential response of notonectids and corixids in the presence of the mosquitofish and a sig- nificant relationship between the presence of mosquitofish and notonectids' decline. Notonectids may suffer from a lack of large zooplankton prey, but may also fall prey to fish or avoid habitats with predatory fish via adult dispersal (Cook and Streams 1984; McCauley and Rowe 2010). Lastly, fish and notonectids may 
also indirectly influence zooplankton's life history traits through the release of kairomones and thus alter prey dynamics (Chakri et al. 2010). All these factors may have led to the decimation of Notonecta species in the study ponds.

In contrast, our study indicated that corixids are less vulnerable to predatory mosquitofish. Whereas notonectids are carnivorous which may increase their vulnerability to competition with mosquitofish for prey, placing corixids in a specific functional feeding group is open to question (Hädicke et al. 2017). Water boatmen have traditionally been considered as organic scrapers (Hutchinson 1993) but recent work indicates they may occupy different trophic niches as predators in littoral and pelagic zones. In addition, they may also occupy benthic substrates as omnivores (Hädicke et al. 2017). Their specific habitat and micro-habitat requirements make them suitable indicators of water quality of lakes (Sav- age 1982). Corixid species composition and diversity may vary according to substrate, organic content, water conduc- tivity, vegetation cover and hydroperiod (Savage 1982; Tully et al. 1991; Bloechl et al. 2010).

Indeed, there is some evidence that corixids are less prone to fish predation than notonectids (Mura et al. 1984). Because of their peculiar head shape, mosquitofish are pre- dominantly surface feeders (Dirnberger and Love 2016) which may make corixids less susceptible because of their bottom-dwelling behavior. Interestingly, surface-dwelling taxa like Gerris thoracicus and Mesovelia vitigera were extirpated from the study ponds in the latest stages of the study. Notable exceptions to the relative vulnerability of corixids from mosquitofish are the small-size Hespero- corixa linnaei and, to a lesser extent, $H$. furtiva. It is known that scent gland secretions of some corixids may confer an effective deterrence against predation (Kovac and Machwitz 1991).

Unfortunately, macroinvertebrates are not the only aquatic organisms that may be undergoing a steep decline in the Numidian landscape. A survey of the amphibians of north-eastern Algeria indicated a precipitous decline of the Algerian newt Pleurodeles poireti (Samraoui et al. 2012). A range of factors may be driving the global decline in amphibians (Stuart et al. 2004), but a number of studies have demonstrated that mosquitofish prey on eggs and larvae thus posing a serious threat to this group (Goodsell and Kats 1999; Komak and Crossland 2000).

\section{Human encroachment and agricultural runoff}

EO-based LULC maps have shown that agriculture around the study sites has increased in a marked way during the last three decades. This expansion of speculative crops (water melons, peanuts) ushered a greater exploitation of the ground water and an unrestricted use of pesticides. In addition, the study area is located close to one the most industrialized region in Algeria with many industrial com- plexes and plants releasing high loads of trace elements in the atmosphere and the hydrological network. High levels of trace elements $(\mathrm{Cd}, \mathrm{Pb})$ have been found in aquatic organ- isms inhabiting the main wadi (river) draining northeastern Algeria (Abdennour et al. 2000; Belabed et al. 2017).

Based on the recorded water conductivity and the absence of algal blooms, there is no evidence that the study sites have suffered from excess organic matter originating from ferti- lizer use on crops. In contrast, there is a widespread use of pesticides in the region where plant protection is essentially achieved through the unrestrained use of insecticides, fungi- cides and herbicides (Mebdoua et al. 2017). Unfortunately, despite the known detrimental effect of agricultural runoff to human health and the environment (Richter 2002; Berenzen et al. 2005; Rasmusen et al. 2012), Algerian regulations are often not enforced and many pesticides (lindane, hexachloro- cyclohexane, etc.), banned elsewhere, are still in use (Alamir et al. 1984).

To make matters worse, there is a widespread non-com- pliance with prescribed concentration and applications of fungicides which are considered as general biocides (Maltby et al. 2009). Another cause of serious concern is the syner- gistic effect of fungicides on non-target organisms in the presence of insecticides (Nørgaard and Cedergreen 2010) or under high temperatures (Müller et al. 2012). Agricultural runoffs and metal contamination can adversely interfere with the development of aquatic organisms and alter food web stability and ecosystem function (Järup 2003).

Furthermore, EO-based data have shown that the natural vegetation cover has shrunk substantially around the study sites. Part of the maquis (scrubland vegetation) has been converted into cultivated plots but overgrazing may also have played a key role in this process. In addition, unre- stricted access to the riparian zones of ponds by grazing livestock can be costly leading to disturbance, vegetation trampling and a decrease in water quality (Clark 1998; Nader et al. 1998). These factors may lead to the loss of aquatic biodiversity and changes in community structure and func- tion (Fleischner 1994). For example, heavily grazed 
ponds can host a lower abundance of aquatic hemipterans, probably through the indirect effect of reduced vegetation cover which may act as a spatial refuge (Bloechl et al. 2010).

Fig. 5 First two principal com-ponents of $\boldsymbol{a}$ variable factor map and $\boldsymbol{b}$ individual factor map. The projected variable "Total" represents total abundance of aquatic hemipterans while codes related to species are found in Table 2. Numbers associated to study sites refer to hydro- logical cycles: $1=1996-$ 1997, 2 = 1997-1998, $3=2010-2011,4=2011-2012$, and $5=2012-2013$. The inset in 6a represents a scree plot

(a) Variables factor map (PCA)

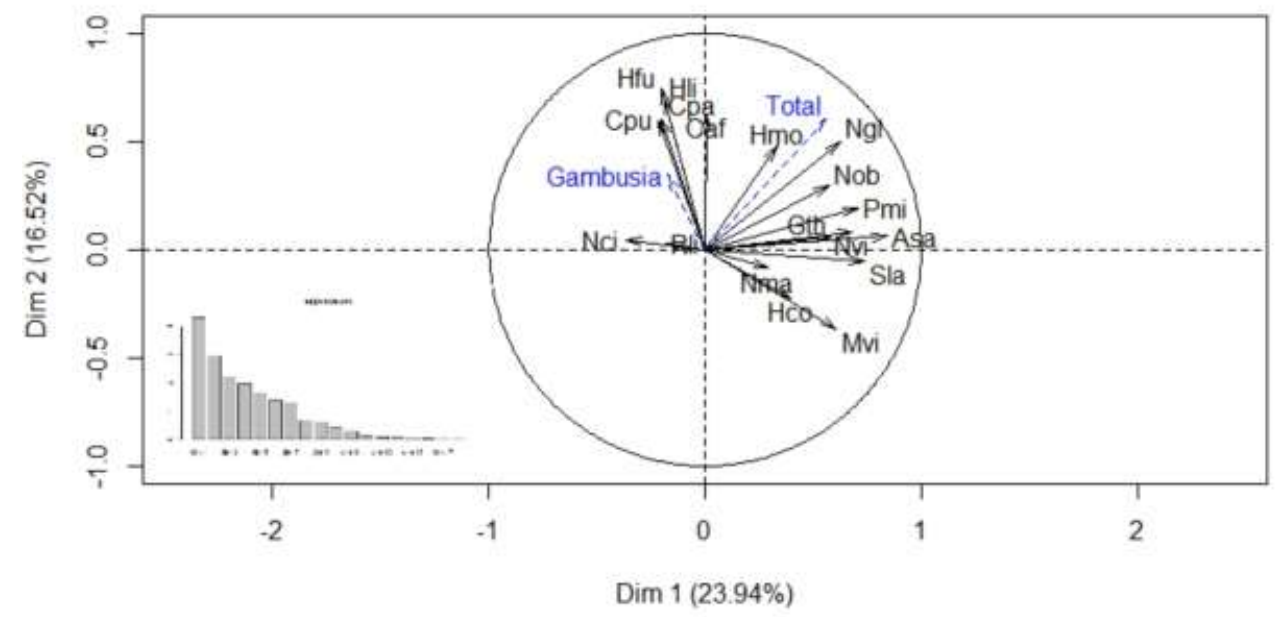

(b) Individuals factor map (PCA)

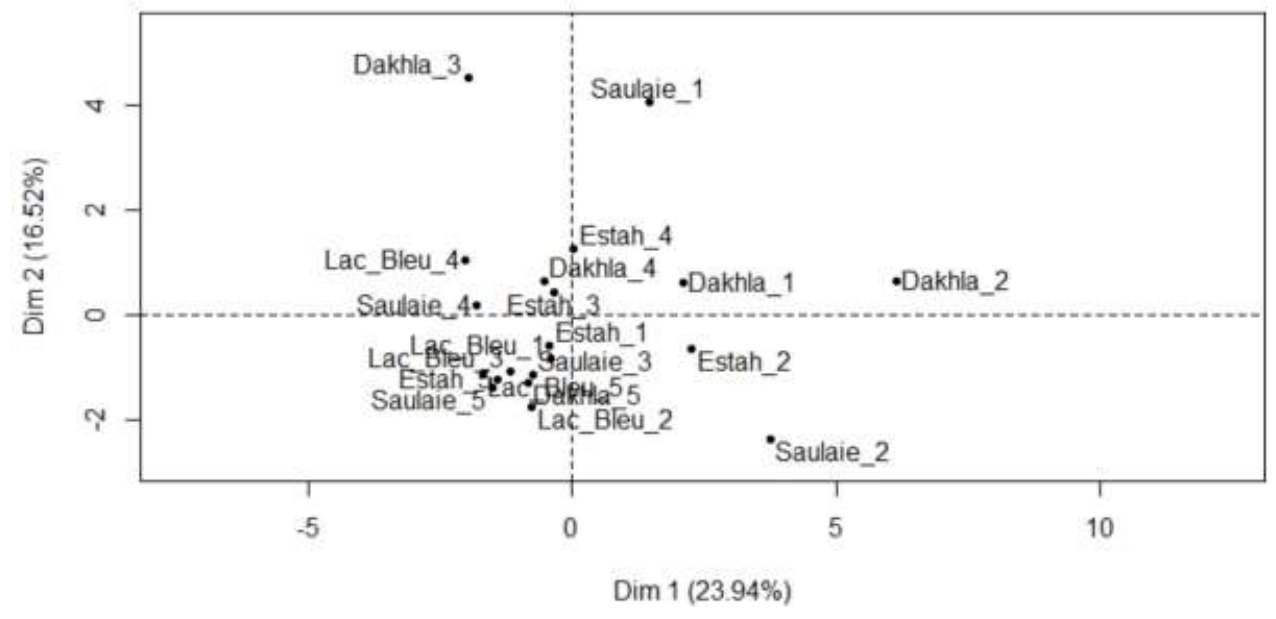


Fig. 6 Mean abundance (and standard error) of Notonectids (a), Corixids (b), and Hesperocorixa moesta (c) according to absence/ presence of mosquitofish. An asterisk in brackets indicates a significant difference

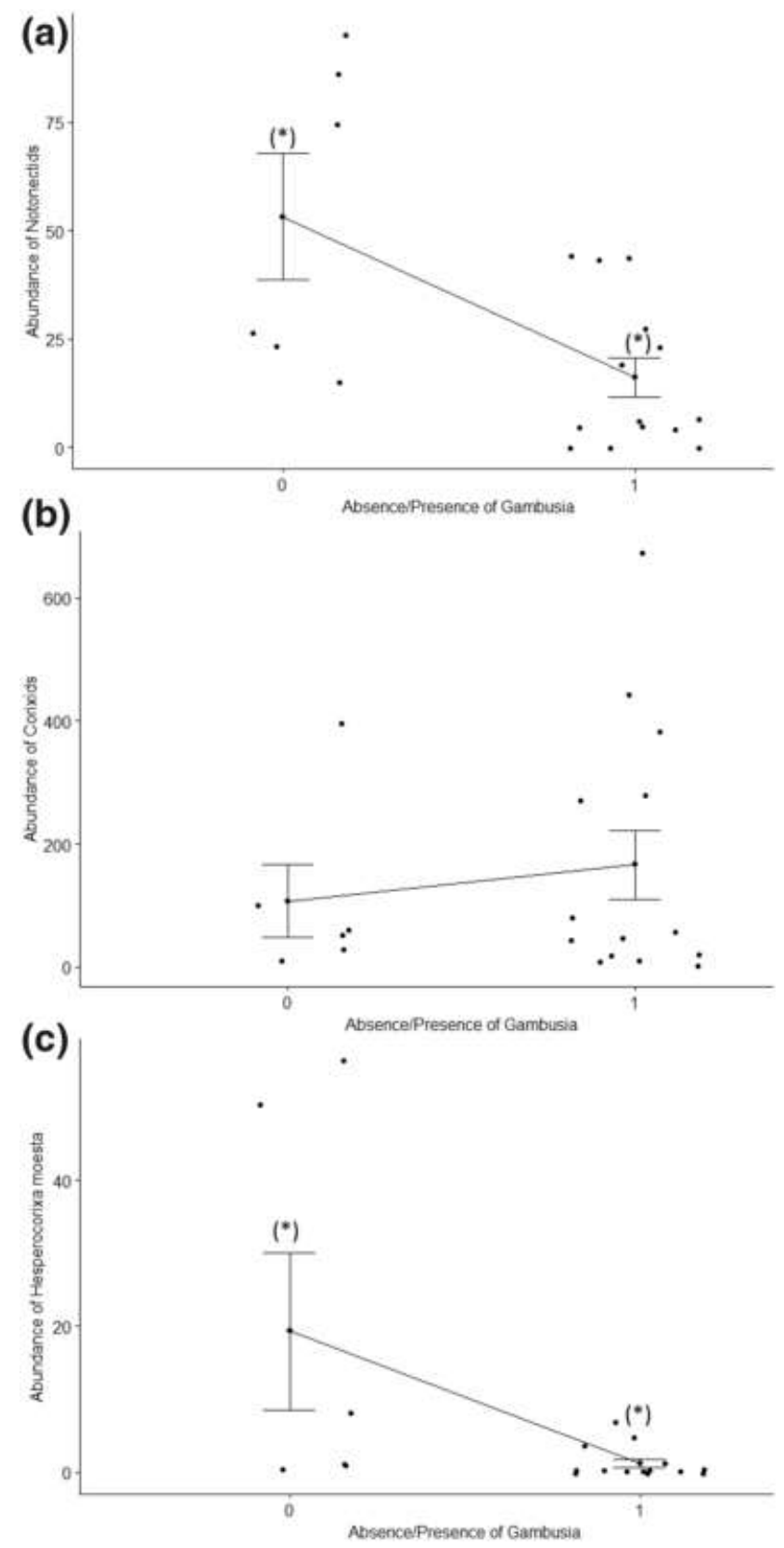

\section{Climate change}

A sustained increase in temperatures across Algeria over the past four decades has been demonstrated by numer- ous studies (Achite and Ouillon 2016; Zeroual et al. 2017). North Africa is also expected to experience increasing heat extremes that are projected to accelerate and be associated with a temperature increase in excess of $6^{\circ} \mathrm{C}$ by the end of the century (Lelieveld et al. 2016). Altered precipitation pat- terns and climate extremes can affect the development and survival of drought-prone macroinvertebrates and dominant predators with repercussions on community structure and function (Wellborn et al. 1996; Dossena et al. 2012). The second cycle at Estah was a typical example of the changes in community structure that occur following a drought- induced eradication of predatory fish.

The collapse of species richness at the study ponds is coherent with studies of the effect of global warming on ecosystems that exhibit a disproportionate loss of spe-cies in higher trophic levels and large body size (Petchey et al. 1999). Although hypotheses about processes driving responses to warming of natural communities are controver- sial ( $O^{\prime} G$ Gorman et al. 2017), increasing temperatures may decrease the amount of dissolved oxygen in surface waters (Carpenter et al. 2011) or affect food webs structure and sta- 
bility by altering predator-prey interaction through changes of the ratio of predator body size to prey body size (Shurin et al. 2012; Gibert and DeLong 2014; Tunney et al. 2014).

\section{Conservation}

Anthropogenic impacts are affecting the structure and func- tion of ecosystems on a global scale (Biesmeijer et al. 2006; Pereira et al. 2010). Likewise, North African ecosystems are facing multiple stressors that are steadily eroding their diversity and our study confirms and complements previous similar studies which highlighted the magnitude of human activities affecting North African wetlands (Samraoui et al. 1992, 2012; Bélair and Samraoui 1994). This finding raises concerns for the conservation of these vulnerable ecosys- tems. Loss of biodiversity may lead to simplified ecosystems which can in turn negatively affect ecosystem functioning, stability and productivity (Pimm et al. 1995; Vitousek et al. 1997). Because alterations of ecosystem processes may adversely affect ecosystems services, they may negatively impact human wellbeings (Farley and Costanza 2010).

The sudden collapse of the biodiversity of the study ponds raises great concerns as Lac Bleu, the only permanent Algerian wetland, is unique for its rare and relict popula- tions of aquatic organisms. In particular, Lac Bleu was for decades the only sanctuary of Urothemis edwardsii, an Afro- tropical relict dragonfly listed as Critically Endangered on both the North African and Mediterranean IUCN Red Lists (Samraoui 2018). Other rare and threatened species include the Endangered Grizzled Pintail Acisoma inflatum, another Afrotropical relict dragonfly, the killifish Aphanius fasciatus, the endemic ray-finned fish Pseudophoxinus callensis, and the Afrotropical relict belostomid Hydrocyrius columbiae.

Our study highlights the formal but fairly ineffective protection provided to internationally important wetlands by including them within national parks, MAB Reserves or designating them as Ramsar sites. Both urgent mitigating steps (halt human encroachment, pollution and overgraz-ing, eradication of invasive species and restoration, etc.) and long-term monitoring of these wetlands are required. In addition, future research should delve deeper into the poten- tial impacts of pesticides and global changes on vulnerable habitats like dune and temporary ponds which are most at risk from water abstraction, drainage, catchment agriculture and unchecked urbanization.

Because of their small size, human encroachment makes ponds particularly exposed to water abstraction, untreated sewage discharges and agricultural runoff. In particular, the presence and concentration of pesticides needs to be studied in more details for the study ponds. Other threats include invasive species, such as mosquitofish which are a threat to freshwater biodiversity that goes often unnoticed (Haiahem et al. 2017).

\section{Conclusions}

In arid North Africa, dune ponds are rare aquatic ecosystems that are sanctuaries to rare, endemic and relict populations of aquatic plants and invertebrates. These hotspots of aquatic biodiversity are seriously threatened by a range of anthropo- genic stressors which are rapidly depleting their communi- ties and disrupting their structure and function. The monitor- ing over a 17-year period of four dune ponds in north-eastern Algeria strongly suggests that invasive fish, agricultural runoff, and an unequivocal temperature rise, may have led to a marked loss of species and abundance of their aquatic hemipteran assemblages. These alarming changes cannot go unheeded and they should prompt urgent mitigation steps to halt the fast eroding North African biodiversity.

Acknowledgements We are most grateful to the Associate Editor and two anonymous referees for their valuable comments and sug-gestions. Help from N. Layachi, F. Terki and M. Mekki is gratefully acknowledged. This work was supported by the Algerian Ministère de l'Enseignement Supérieur et de la Recherche Scientifique (MESRS).

\section{Compliance with ethical standards}

Conflict of interest The authors declare that they have no conflict of interest.

Ethical approval This study was approved by the Algerian Ministère de l'Enseignement Supérieur et de la Recherche Scientifique (M.E.S.R.S.) and all procedures followed were in accordance with international ethi- cal standards.

Research involving human participants The research involved no human participant.

Informed consent All the authors are in agreement with the version submitted and are in agreement with its publication in Journal of Insect Conservation. 


\section{References}

Abdennour C, Smith BD, Boulakoud MS, Samraoui B, Rainbow PS (2000) Trace metals in marine, brackish and freshwater prawns (Crustacea, Decapoda) from northeast Algeria. Hydrobiologia 432:217-227

Achite M, Ouillon S (2016) Recent changes in climate, hydrology and sediment load in the Wadi Abd, Algeria (19702010). Hydrol Earth Syst Sci 20:1355-1372

Alamir B, Venant A, Bac LR (1984) Evaluation of pollution levels by analysis of the pesticide residues in Algerian sheep. In: Chambers PL, Preziosi P, Chambers CM (eds) Disease, metabolism and reproduction in the toxic response to drugs and other chemicals. Archives of Toxicology (Supplement), vol 7. Springer, Berlin, pp 451-452

Annani F, Alfarhan AH, Samraoui B (2012) Aquatic Hemiptera of northeastern Algeria: distribution, phenology and conservation. Rev Ecol Terre Vie 67:1-13

Batzer DP, Wissinger SA (1996) Ecology of insect communities in nontidal wetlands. Annu Rev Entomol 41:75-100 Belabed BE, Meddour A, Samraoui B, Chenchouni H (2017) Modeling seasonal and spatial contamination of surface waters and upper sediments with trace metal elements across industrialized urban areas of the Seybouse watershed in North Africa. Environ Monit Assess 189:265. https://doi.org/10.1007/s10661-017-5968-5

Bélair G de, Samraoui B (1994) Death of a lake: Lac Noir in northeastern Algeria. Environ Conserv 21:169-172

Berenzen N, Kumke T, Schulz HK, Schulz R (2005) Macroinvertebrate community structure in agricultural streams: impact of runoff- related pesticide contamination. Ecotoxicol Environ Saf 60:37-46

Biesmeijer JC, Roberts S, Reemer M et al (2006) Parallel declines in pollinators and insect-pollinated plants in Britain and the Nether- lands. Science 31:351-354

Bilton DT, McAbendroth LC, Nicolet P, Bedford A, Rundle SD, Foggo A, Ramsay PM (2009) Ecology and conservation status of tem- porary and fluctuating ponds in two areas of Southern England. Aquat Conserv 19:134-146

Bloechl A, Koenemann S, Phillippi B, Melber A (2010) Abundance, diversity and succession of aquatic Coleoptera and Heteroptera in a cluster of artificial ponds in the North German Lowlands. Limnologica 40:215-225

Botsford LW, Vondracek B, Wainwright TC, Linden AL, Kope RG, Reed DE, Cech J (1987) Population development of the Mos- quitofish, Gambusia affinis, in rice fields. Environ Biol Fish 20:143-154

Brinson MM, Malvárez AI (2002) Temperate freshwater wetlands:

types, status, and threats. Environ Conserv 29:115-133

Bunn SE (2016) Grand challenge for the future of freshwater eco-

systems. Front Environ Sci 4:21. https://doi.org/10.3389/fenvs .2016.00021

Cardoso P, Erwin TL, Borges PAV, New TR (2011) The seven impediments in invertebrate conservation and how to overcome them. Biol Conserv 144:2647-2655

Carpenter SR, Stanley EH, Vander Zanden MJ (2011) State of the World's freshwater ecosystems: physical, chemical, and biologi- cal changes. Annu Rev Environ Resour 36:75-99

Céréghino R, Boix D, Cauchie H-M, Martens K, Oertli B (2014) The ecological role of ponds in a changing world.

Hydrobiologia 723:1-6

Chakri K, Touati L, Alfarhan AH, Al-Rasheid KAS, Samraoui B (2010) Effect of vertebrate and invertebrate kairomones on the life history of Daphnia magna Straus (Crustacea: Branchiop- oda). C R Biol 333:836-840

Clark EA (1998) Landscape variables affecting livestock impacts on water quality in the humid temperate zone. Can J Plant Sci 78:181-190

Collinson NH, Biggs J, Corfield A, Hodson MJ, Walker D, Whit- field M, Williams PJ (1995) Temporary and permanent ponds: an assessment of the effects of drying out on the conservation value of aquatic macroinvertebrates communities. Biol Conserv 74:125-133

Conrad KF, Warren MS, Fox R, Parsons MS, Woiwod IP (2006) Rapid declines of common, widespread British moths provide evidence of an insect biodiversity crisis. Biol Conserv 132:279-291

Cook WL, Streams FA (1984) Fish predation on Notonecta (Hemip- tera): relationship between prey risk and habitat utilization. Oeco- logia 64:177-183

Davies B, Biggs J, Williams P, Whitfield M, Nicolet P, Sear D, Bray S, Maund S (2008) Comparative biodiversity of aquatic habitats in the European agricultural landscape. Agric Ecosyst Environ 125:1-8

Della Bella V, Bazzanti M, Chiarotti F (2005) Macroinvertebrate diversity and conservation status of Mediterranean ponds in Italy: water permanence and mesohabitat influence. Aquat Con- serv 15:583-600

Demnati F, Samraoui B, Allache F, Sandoz A, Ernoul L (2017) A literature review of Algerian salt lakes: values, threats and impli- cations. Environ Earth Sci 76:127. https://doi.org/10.1007/s1266 5-017-6443-x

Dirnberger JM, Love J (2016) Seasonal specialization and selectivity of the Eastern Mosquitofish, Gambusia holbrooki, toward planktonic prey. Southeast Nat 15:138-152

Dirzo R, Young HS, Galetti M, Ceballos G, Isaac NJ, Collen B (2014) Defaunation in the anthropocene. Science 345:401-406

Dossena M, Yvon-Durocher G, Grey J, Montoya JM, Perkins DM, Trimmer M, Woodward G (2012) Warming alters

community size structure and ecosystem functioning. Proc R Soc Lond B 279:3011-3019 
Downing JA (2010) Emerging global role of small lakes and ponds:little things mean a lot. Limnetica 29:9-24

Dudgeon D, Arthington AH, Gessner MO, Kawabata Z, Knowler D, Lévêque C,. Naiman RJ,. Prieur-Richard A-H, Soto D, Stiassny MLJ, Sullivan CA (2006) Freshwater biodiversity: importance, threats, status and conservation challenges. Biol Rev 81:163-182

Farley J, Costanza R (2010) Payments for ecosystem services: from local to global. Ecol Econ 69:2060-2068

Fleischner TL (1994) Ecological costs of livestock grazing in western North America. Conserv Biol 8:629-644

Gibert JP, DeLong JP (2014) Temperature alters food web body-size structure. Biol Lett 10:20140473

Goodsell JA, Kats LB (1999) Effect of introduced Mosquitofish on Pacific Treefrogs and the role of alternative prey.

Conserv Biol 13:921-924

Hädicke CW, Rédei D, Kment P (2017) The diversity of feeding habits recorded for water boatmen (Heteroptera:

Corixoidea) world-wide with implications for evaluating information on the diet of aquatic insects. Eur J Entomol

114:147-159

Haiahem D, Touati L, Baaziz N, Samraoui F, Alfarhan AH, Samraoui B (2017) Impact of eastern mosquitofish, Gambusia holbrooki, on temporary ponds: insights on how predation may structure zoo- plankton communities. Zool Ecol

27:124-132

Hallmann CA, Sorg M, Jongejans E et al (2017) More than 75 percent decline over 27 years in total flying insect biomass in protected areas. PLoS ONE 12:e0185809. https://doi.org/10.1371/journ al.pone.0185809

Hollis GE (1992) The causes of wetland loss and degradation in the Mediterranean. In: Finlayson CM, Davis TJ (eds)

Managing Medi- terranean wetlands and their birds. IWRB, Slimbridge, pp 83-90

Hurlbert SH, Zedler J, Fairbanks D (1972) Ecosystem alteration by Mosquitofish Gambusia affinis predation. Science 175:639-

641

Hutchinson GE (1993) A treatise on limnology. In: Edmondson YH (ed) The zoobenthos, vol IV. Wiley, New York Jansson A (1977) Micronectae (Heteroptera, Corixidae) as indicators of water quality in two lakes in southern Finland.

Ann Zool Fennici 14:118-124

Järup L (2003) Hazards of heavy metal contamination. Br Med Bull 68:167-182

Klecka J (2014) The role of a water bug, Sigara striata, in freshwater food webs. Peer J 2:e389

Komak S, Crossland MR (2000) An assessment of the introduced Mosquitofish (Gambusia affinis holbrooki) as a

predator of eggs, hatchlings and tadpoles of native and non-native anurans. Wildl Res 27:185-189

Kovac D, Machwitz U (1991) The function of the metathoracic scent gland in corixid bugs (Hemiptera, Corixidae):

secretion-grooming on the water surface. J Nat Hist 25:331-340

Lelieveld J, Proestos Y, Hadjinicolaou P, Tanarhte M, Tyrlis E, Zit- tis G (2016) Strongly increasing heat extremes in

the Middle East and North Africa (MENA) in the 21st century. Clim Chang 137:245-260

Losey JE, Vaughan M (2006) The economic value of ecological services provided by insects. Bioscience 56:311-323

Magurran AE (1988) Ecological diversity and its measurement. Croom Helm, London

Maltby L, Brock TC, Van den Brink PJ (2009) Fungicide risk assess- ment for aquatic ecosystems: importance of

interspecific variation, toxic mode of action, and exposure regime. Environ Sci Technol 43:7556-7563

McCauley SJ, Rowe L (2010) Notonecta exhibit threat-sensitive, predator-induced dispersal. Biol Lett 6:449-452

Mebdoua S, Lazali M, Ounane SM, Tellah S, Nabi F, Ounane G (2017) Evaluation of pesticide residue in fruits and

vegetables from Alge- ria. Food Addit Contam Part B 10:91-98

Mitchell M, Bennett EM, Gonzalez A (2013) Linking landscape con- nectivity and ecosystem service provision: current

knowledge and research gaps. Ecosystems 16:894-908

Mitsch WJ, Bernal B, Hernandez ME (2015) Ecosystem services of wetlands. Intl J Biodivers Sci Eco Serv Mgt 11:1-4

Müller R, Seeland A, Jagodzinski LS, Diogo JB, Nowak C, Oehl-

mann J (2012) Simulated climate change conditions unveil the toxic potential of the fungicide pyrimethanil on the midge Chironomus riparius: a multigeneration experiment. Ecol Evol 2:196-210

Mura T, Takahashi RM, Wilder WH (1984) Impact of the mos- quitofish (Gambusia affinis) on a rice field ecosystem when used as a mosquito control agent. Mosq News 44:510-517

Murdoch WW, Scott MA, Ebsworth P (1984) Effects of the general predator, Notonecta (Hemiptera) upon a freshwater community. J Anim Ecol 53:791-808

Nader GA, Tate KW, Atwill ER, Bushnell J (1998) Water quality effect of rangeland beef cattle excrement. Rangelands 20:1925

Nicolet P, Biggs J, Fox G, Hodson MJ, Reynolds C, Whitfield M, Williams P (2004) The wetland plant and macroinvertebrates assemblages of temporary ponds in England and Wales. Biol Conserv 120:261-278

Nørgaard KB, Cedergreen N (2010) Pesticide cocktails can interact synergistically on aquatic crustaceans. Environ Sci Pollut Res 17:957-967

O'Gorman EJ, Zhao L, Pichler DE, Adams G, Friberg N, Rall BC, Seeney A, Zhang HY, Rauman DC, Woodward G (2017)

Unexpected changes in community size structure in a natural warm- ing experiment. Nat Clim Chang 7:659-663 
Oertli B, Joye DA, Castella E, Juge R, Cambin D, Lacahvanne J-B (2002) Does size matter? The relationship between pond area and biodiversity. Biol Conserv 104:59-70

Oertli B, Biggs J, Céréghino R, Grillas P, Joly P, Lacahvanne JB (2005) Conservation and monitoring of pond biodiversity: introduction. Aquat Conserv 15:535-540

Papáček M (2001) Small aquatic and ripicolous bugs (Heteroptera: Nepomorpha) as predators and prey: the question of economic importance. Eur J Entomol 98:1-12

Pereira HM, Leadley PW, Proenca V et al (2010) Scenarios for global biodiversity in the 21st century. Science 330:1496-1501 Petchey OL, McPhearson PT, Casey TM, Morin PJ (1999) Envi- ronmental warming alters food-web structure and ecosystem function. Nature 402:69-72

Pimm SL, Russell GJ, Gittleman JL, Brooks TM (1995) The future of biodiversity. Science 269:347-350

Polhemus JT, Polhemus DA (2008) Global diversity of true bugs (Heteroptera; Insecta) in freshwater.

Hydrobiologia 595:379-391

Pyke GH (2008) Plague Minnow or Mosquito Fish? A review of the biology and impacts of introduced Gambusia species. Annu Rev Ecol Evol Syst 39:171-191

R Development Core Team (2017) R: a language and environment for statistical computing. R Foundation for Statistical Comput-ing, Vienna

Rasmusen JJ, Wiberg-Larsen P, Baattrup-Pedersen A, Friberg N, Kronvang B (2012) Stream habitat structure influences mac- roinvertebrate response to pesticides. Environ Pollut 60:37-46

Richter ED (2002) Acute human pesticide poisonings. In: Pimentel D (ed) Encyclopedia of pest management. Dekker, New York, pp 3-6

Sala OE, Chapin FS, Armesto JJ et al (2000) Global biodiversity scenarios for the year 2000. Science 287:1770-1774 Samraoui B (2002) Branchiopoda (Ctenopoda and Anomopoda) and Copepoda from eastern Numidia. Algeria Hydrobiol 470:173-179

Samraoui B (2018) The hand of man or Santa Rosalia's blessing? A rebuttal of the paper "on the restoration of the relict popula- tion of a dragonfly Urothemis edwardsii Selys (Libellulidae: Odonata) in the Mediterranean". J Insect Conserv 22:345-350

Samraoui B, Samraoui F (2008) An ornithological survey of Alge- rian wetlands: important bird areas, Ramsar sites and threatened species. Wildfowl 58:71-96

Samraoui B, Bélair G de, Benyacoub S (1992) A much-threatened lake: Lac des Oiseaux in northeastern Algeria.

Environ Conserv 19:264-267+ 276

Samraoui B, Benyacoub S, Mecibah S, Dumont HJ (1993) Afrotropi-cal libellulids (Insecta: Odonata) in the lake district of El Kala, North-East Algeria, with a rediscovery of Urothemis e. edwardsi (Selys) and Acisoma panorpoides ascalaphoides (Rambur). Odonatologica 22:365-372

Samraoui B, Bélair G de (1997) The Guerbes-Senhadja wetlands (N.E. Algeria) Part I: an overview. Ecologie 28:233-250 Samraoui B, Bélair G de (1998) Les zones humides de la Numidie Orientale: Bilan des connaissances et perspectives de gestion. Synthèse 4:1-90

Samraoui B, Segers H, Maas S, Baribwegure D, Dumont HJ (1998) Rotifera, Cladocera, Copepoda, and Ostracoda from coastal wet- lands in northeast Algeria. Hydrobiologia 386:183-193

Samraoui B, Samraoui F, Benslimane N, Alfarhan AH, Al-Rasheid KAS (2012) A precipitous decline of the Algerian Newt Pleu-rodeles poireti Gervais, 1835 and other changes in the status of amphibians of Numidia, Northeastern Algeria. Rev Ecol Terre Vie 67:71-82

Savage AA (1982) Use of water boatmen (Corixidae) in the classification of lakes. Biol Conserv 23:55-70

Savage AA (1990) The distribution of Corixidae in lakes and the ecological status of the North west Midlands Meres. Field Stud 7:516-530

Shurin JB (2001) Interactive effects of predation and dispersal on zooplankton communities. Ecology 82:3404-3416

Shurin JB, Clasen JL, Greig HS, Kratina P, Thompson PL (2012) Warming shifts top-down and bottom-up control of pond food web structure and function. Philos Trans R Soc Lond B 367:3008-3017

Stuart SN, Chanson JS, Cox NA, Young BE, Rodrigues ASL, Fis- chman DL, Waller RW (2004) Status and trends of amphibian declines and extinctions worldwide. Science 306:1783-1786

Tachet H, Richoux P, Bournaud M, Usseglio-Polatera P (2010) Invertébrés d'eau douce: systématique, biologie, écologie. CNRS Editions, Paris

Tebibel S (1992) Hémiptères aquatiques d’Algérie. Clés dichotom-iques, inventaire des espèces, distribution en Algérie et dans le monde. Dissertation, University of Algiers, USTHB

Thomas JA, Telfer MG, Roy DB et al (2004) Comparative losses of British butterflies, birds, and plants and the global extinction crisis. Science 303:1879-1881

Tully O, McCarthy TK, O'Donnell D (1991) The ecology of the Corixidae (Hemiptera: Heteroptera) in the corrib catchment. Irel Hydrobiol 210:161-169 
Tunney TD, McCann KS, Lester NP, Shuter BJ (2014) Effects of dif- ferential habitat warming on complex communities. Proc Natl Acad Sci USA 111:8077-8082

Vitousek PM, Mooney HA, Lubchenco J, Melillo JM (1997) Human domination of Earth's ecosystems. Science 277:494-499 Vörösmarty C, McIntyre PB, Gessner MO, Dudgeon D, Prusevich A, Green P, Glidden S, Bunn SE, Sullivan CA, Reidy Liermann C, Davies PM (2010) Global threats to human water security and river biodiversity. Nature 467:555-561 Wellborn GA, Skelly DK, Werner EE (1996) Mechanisms creating community structure across a freshwater habitat gradient. Annu Rev Ecol Syst 27:337-363

Wilbur HM (1997) Experimental ecology of food webs: complex systems in temporary ponds. Ecology 78:2279-2302 Williams P, Whitfield M, Biggs J, Bray S, Fox G, Nicolet P, Sear D (2003) Comparative biodiversity of rivers, streams, ditches and ponds in an agricultural landscape in Southern England. Biol Conserv 115:329-341

Zacharias I, Dimitrou E, Dekker A, Dorsman E (2007) Overview of temporary ponds in the Mediterranean region: threats, manage- ment and conservation issues. J Environ Biol 28:1-9

Zaret TM (1980) Predation and freshwater communities. Yale University Press, New Haven Zeroual A, Assani A, Meddi M (2017) Combined analysis of tem- perature and rainfall variability as they relate to climate indices in Northern Algeria over the 1972-2013 period. Hydrol Res 48:584-595 